\title{
PReS13-SPK-1028: Activity and damage - we have to measure them
}

\author{
H Brunner \\ From 20th Pediatric Rheumatology European Society (PReS) Congress \\ Ljubljana, Slovenia. 25-29 September 2013
}

\section{Background}

Childhood-onset SLE is a complex multiorgan disease. In order to judge the need of medical intervnetions and the patient benefits from them, measurement disease activity and damage are key. Furthermore, important improvement and deterioration of disease needs to be ascertained. Such measurement are the basis for clinical trial aimed at identifying improved medications and are needed to judge the benefits of medical interventions in general.

\section{Methods}

An overview will be provided about current surrogate and biological markers of global and disease specific disease activity and damage. Focus will be placed on the relevance for children with SLE and current research activities, particularly NPSLE and lupus nephritis.

\section{Results \& deliverables}

Upon completion of the presentation the audience will $h$ ave a firm understanding about the suitability of individual measures of disease activity and their differences. Measures include the various versions of the SLEDAI and BILAG, as well as SLE flare tools. The SLICC Damage Index and its pediatric version will be discussed in addition to previously validated measures of clinically relevant improvment and disease flare. Additionally, biomarkers of lupus nephritis as they are suited to help diagnose kidney disease and anticipate changes in the activity and chronicity of kidney lesions will be available. Some novel imaging biomarkers of neuropsychiatric damage will be reviewed.

\section{Disclosure of interest}

None declared.

Pediatrics, Cincinnati Children's Hospital Medical Center, Cincinnati, USA
Published: 5 December 2013

doi:10.1186/1546-0096-11-S2-122

Cite this article as: Brunner: PReS13-SPK-1028: Activity and damage - we have to measure them. Pediatric Rheumatology 2013 11(Suppl 2):I22.

\section{Submit your next manuscript to BioMed Central and take full advantage of: \\ - Convenient online submission \\ - Thorough peer review \\ - No space constraints or color figure charges \\ - Immediate publication on acceptance \\ - Inclusion in PubMed, CAS, Scopus and Google Scholar \\ - Research which is freely available for redistribution

() Biomed Central

(c) 2013 Brunner; licensee BioMed Central Ltd. This is an Open Access article distributed under the terms of the Creative Commons Attribution License (http://creativecommons.org/licenses/by/2.0), which permits unrestricted use, distribution, and reproduction in any medium, provided the original work is properly cited. The Creative Commons Public Domain Dedication waiver (http://creativecommons.org/publicdomain/zero/1.0/) applies to the data made available in this article, unless otherwise stated. 